\title{
ÚJ GENERÁCIÓS TERAHERTZES IMPULZUS FORRÁSOK
}

\author{
Tóth György ${ }^{1,2}$, Pálfalvi Lászlón ${ }^{1}$, Tibai Zoltán ${ }^{1}$, Krizsán Gergö ${ }^{1,2}$, Fülöp József András ${ }^{1,2}$, \\ Almási Gábor ${ }^{1,2}$, Hebling János ${ }^{1,2,3}$
}

\author{
${ }^{1}$ PTE-TTK Fizikai Intézet, 7624 Pécs, Ifjúság u. 6, Magyarország \\ ${ }^{2}$ Szentágothai János Kutatóközpont, 7624 Pécs, Ifjúság u. 20, Magyarország \\ ${ }^{3}$ MTA-PTE Nagyintenzitású Terahertzes Kutatócsoport, 7624 Pécs, Ifjúság u. 6, Magyarország
}

DOI: https://doi.org/10.14232/kvantumelektronika.9.35

\section{Bevezetés}

Nagy energiájú terahertzes (THz-es) impulzusok előállításának elterjedt módja a lítium niobát (LN) kristályban történő döntött impulzusfrontú gerjesztés [1]. A technikát széles körben alkalmazzák olyan területeken, ahol egyciklusú, nagy térerősségü THz-es impulzusokra van szükség [2]. Közel tíz éve felvetődött annak a lehetösége, hogy extrém nagy térerősségek esetén a THz-es impulzusok alkalmasak lehetnek töltött részecskék manipulálására, gyorsítására is [3]. Ezen elképzelésre alapozva megszületett az első impulzus üzemü THz-es elektrongyorsító [4]. Számos tanulmány mutatott rá, hogy amennyiben a jelenleg előállított impulzusenergiáknál nagyobb energiájú THz-es impulzusokat tudnánk előállítani, úgy egyrészt jóval hatékonyabb gyorsítást érhetnénk el [5], másrészt új területek nyílhatnak meg a THz-es impulzusok alkalmazása számára [6-8].

A döntött impulzusfrontú elrendezés azonban nem alkalmas 1 mJ-nál jelentősen nagyobb energiájú THz-es impulzusok létrehozására [9-10]. Ezt a korlátot három fó okra vezethetjük vissza [10-11]: 1) a keltésre használt kristály nagy ékszögü prizma, így az THz-es nyaláb keresztiránya mentén a sugárzás különböző utakat tesz meg a kristályban. Ennek eredményeként a THz-es sugárzás térerősséglefutása nem lesz homogén a nyaláb keresztmetszete mentén. 2) A döntött impulzusfront előállítása jelentős szögdiszperzióval jár, mely rövid pumpáló impulzusok esetén az impulzusalak gyors megváltozásához vezet. Ez a hatás jelentősen redukálja a keltési hatásfokot. 3) A döntött impulzus kristályba való leképzéséből eredő leképzési hibák is jelentősen korlátozzák az alkalmazható pumpa nyalábméretét.

Ezen limitáló tényezőket igyekezett feloldani a közelmúltban számos új elképzelés [13-17], melyek közül a legpontosabb számítások alapján is [10] a Pécsi Tudományegyetemen tett javaslatoknak [14-17] valóban meghatározó szerepe lehet a nagy intenzitású THz-es impulzusok előállításának területén.

\section{Eredmények}

Három új típusú THz-es forrást javasoltunk a közelmúltban [14-16], melyek közül eddig egynek a müködését demonstráltuk [18].

a.) NLES - leképzéssel

Az első javaslatunkat az 1. ábra mutatja be: a LN kristály rács felőli fala mikrostrukturált szerkezetű (tipikusan 50-70 $\mu$ m-es lépcsők), és a LN döntve van olyan mértékben, amilyen mértékü impulzusfront döntésre van szükség a LN kristály belsejében a sebességillesztés megvalósítása érdekében [1,14] A transzmissziós rács - lencse rendszer arra szolgál, hogy ugyanilyen mértékü impulzusfront dőléssel rendelkezzen a pumpáló impulzus mielőtt belép a LN kristályba. Így teljes mértékben megszüntettünk minden olyan problémát, melyet a nagy ékszögü prizma alakú kristály használata eredményezett, hiszen az alkalmazott kristály ezzel a megoldással sík-párhuzamos lehet. 
Ennél az elrendezésnél az optikai rács - lencse rendszernek jelentősen kisebb döntési szöggel rendelkező impulzusfrontot kell csak létrehoznia, mint a hagyományos elrendezés esetén. (A szükséges dőlési szögek tangenseinek aránya a LN csoporttörésmutatójával egyenlő.) Ez jelentősen megnövelt THz keltési hosszat eredményez. Ugyanakkor a LN kristályban létrehozott impulzusfront dőlése nem folytonos, hanem szegmentált (lásd 1. b ábra). Az elrendezéssel a THz-es energia tökéletesen skálázható a pumpa nyalábméretével egészen a leképzési korlátok megjelenéséig. Ez 200 fs-os impulzushossz esetén $2 \mathrm{~cm}$-nél is nagyobb nyalábátmérőt jelent [14].

a)

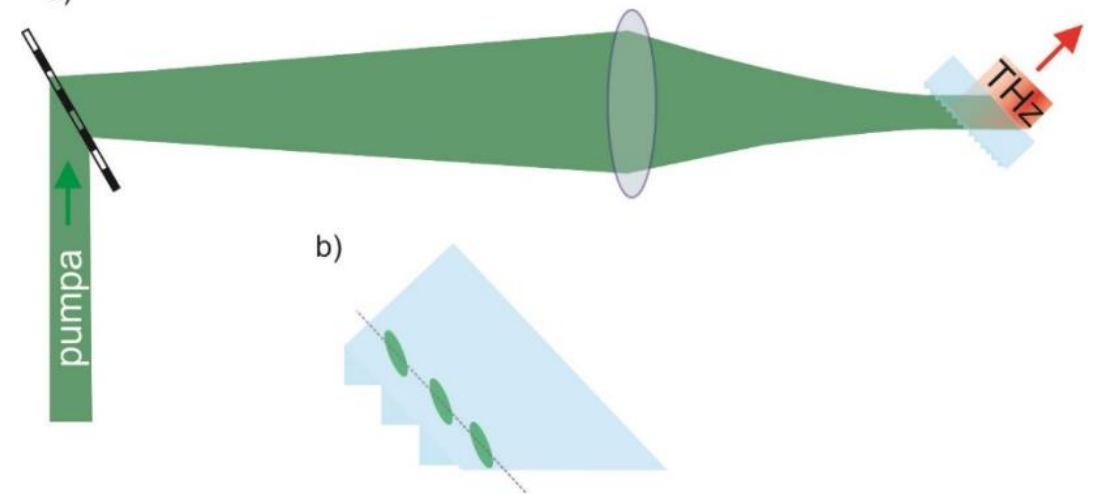

1. ábra. „NLES - leképzéssel” elrendezés (a) és a szegmentált döntött impulzusfront a kristályban (b)

\section{b.) NLES - leképzés nélkül}

Rámutattunk, hogy lehetőség van az NLES használatára abban az esetben is, ha elhagyjuk a leképző elemet [15] (2. ábra), ezzel megszüntetve a leképzésből eredő korlátozó tényezőket. A nagy diffrakciós hatásfok elérése érdekében elsősorban olyan geometriákat vizsgáltunk, amikor a pumpa nyaláb Littrow-szögben esik a rácsra. Ebben az esetben azonban a szükséges impulzusfront-döntés kialakításához le kell mondanunk arról, hogy a rács és a kristály oldalai mind párhuzamosak legyenek. Számításaink alapján Littrow-szögű elrendezés esetén jó hatásfokkal, jó minőségű THz-es nyaláb állítható elő 1030 nm-es pumpálási hullámhosszon 1570 vonal/mm karcolatsürüségủ rácsot használva. Ebben az esetben a pumpa $54^{\circ}$-os szöget zár be a diffrakciós rács normálisával, a rács és a kristály rács felőli felülete párhuzamos, a kristály hátlapja azonban $9^{\circ}$-os szöget zár be ezzel az előlappal.

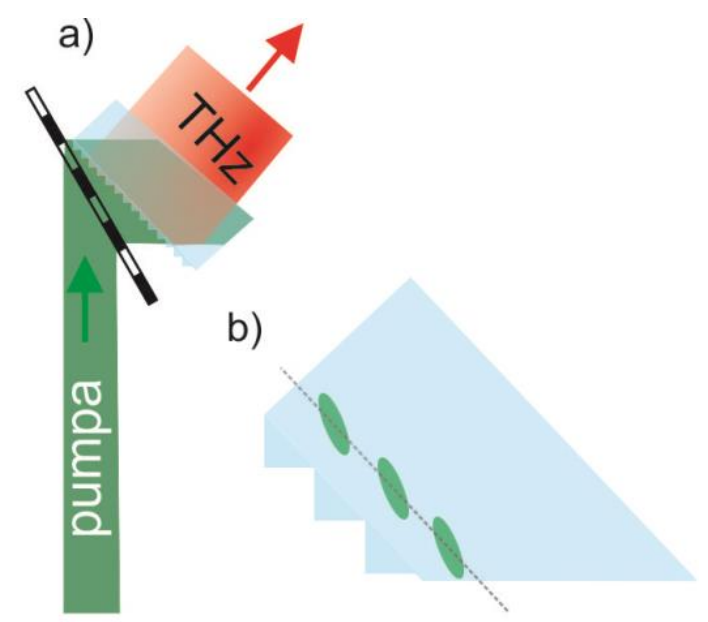

2. ábra „NLES - leképzés nélkül” elrendezés (a) és a szegmentált döntött impulzusfront a kristályban 
Az elrendezés teljes mértékben megszünteti a leképzési hibákat, de csak redukálja (igen erős mértékben) a prizma alakból eredő problémákat. Amennyiben a diffrakciós rácsot nem Littrowszögben használjuk, úgy megoldható, hogy a rács és a kristály oldalai is párhuzamosak legyenek egymással. Ilyen esetben a pumpa merőlegesen esik a 870 vonal/mm-es karcolatsürüségü rácsra, a Littrow-szögtől való eltérés $26,5^{\circ}$-, mely közel $70 \%$-os diffrakciós veszteséget okoz.

A két szélső helyzet között (Littrow szögü elrendezés, amikor a pumpa és a rács normálisa $54^{\circ}$-os szöget zár be egymással, illetve párhuzamos falú kristály párhuzamos rácsállással, amikor a pumpa merőlegesen esik a rácsra) számításaink alapján a legjobb kompromisszum, ha a Littrow-szögtől 10-al térünk el. Ez esetünkben 1360 vonal/mm-es karcolatsürüségü rácsnál valósítható meg, melynek diffrakciós hatásfoka $80 \%$ körül van. A pumpa rácsra való beesésének szöge $35^{\circ}$, a kristály ékszöge $4,5^{\circ}$, mely jelentős nyalábminőség javulást és használható kristályfelület növelést tesz lehetővé [19]. Felvetődött térfogati holografikus rácsok használata is, mellyel jóval nagyobb hatásfokkal lehet elérni azt az esetet, amikor mind a kristály falai, mind a rács párhuzamosak.

\section{c.) Reflexiós $N L S$}

Az előzőektől eltérő koncepció a reflexiós NLS (Nonlinear Slab), mely egy, a hátoldalán reflexiós rácsként kialakított párhuzamos falú kristályból áll (3. ábra). A sebességillesztés itt a hagyományos döntött impulzusfrontú gerjesztéshez hasonlóan, egy rácsról történő diffrakciót követően alakul ki, de ezúttal ez a diffrakció nem a kristályon kívül, hanem a kristályban történik. A THz-keltés a hátoldalról történő diffrakciót követően kezdődik.

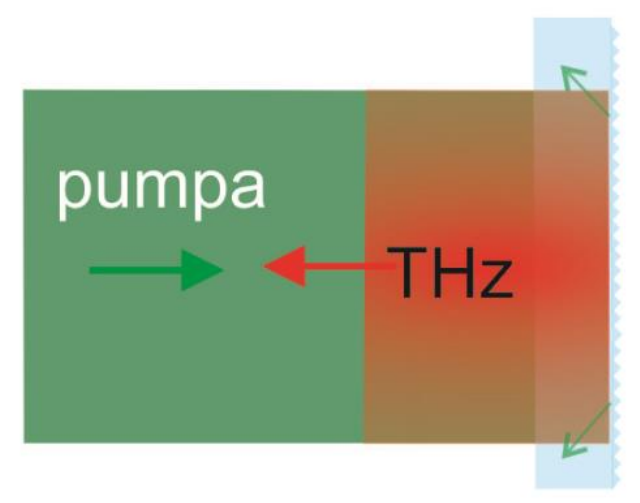

3. ábra Reflexiós NLS elrendezés. A balra haladó THz-es impulzust a kristály hátoldalán diffraktálódott, döntött, már balra haladó pumpa impulzus alakítja ki.

Az elrendezés mind az ékszögből, mind a leképzésből eredő problémákat megszünteti, azonban a szögdiszperzió ugyanúgy megmarad, mind a hagyományos döntött impulzusfrontú elrendezés esetén. A keletkező THz-es nyaláb azonban kiváló minőségü lesz, a keltési hatásfok reális értéke 1-2\% körül lehet [9]. Egyszerübb számítások, melyek nem veszik figyelembe a keletkező THz-es impulzus pumpára való visszahatását, ennél lényegesen nagyobb hatásfokot jósolnak [19]. Az elrendezés rendkívülisége, hogy szemben a korábbi technikákkal, itt semmilyen elvi korlát nincs, ami a használható pumpáló folt méretét korlátozná. Megfelelően nagy kristály esetén tehát reflexiós NLS esetén a THz-es energia a pumpáló impulzus energiájával skálázható.

Mivel még nem bizonyított, hogy a kristály felületén optikai minőségü rácsot tudnak létrehozni, olyan megoldást is javasoltunk, ahol a téglatest alakú kristályhoz illesztő folyadékkal illesztettünk egy külső 
reflexiós rácsot [17]. Ez a megoldás nagyban megkönnyítheti ezen típusú THz-forrás tömeggyártását is.

\section{3. Összefoglalás}

Az elmúlt bő három évben olyan új LN alapú THz-es forrásokat fejlesztettünk ki, melyek a döntött impulzusfrontú technikához hasonlóan mérföldkövet jelenthetnek a nagy energiájú THz-es impulzusok elöállításának a területén. A három különböző forrás különböző felhasználási lehetőségeket biztosít. Míg a leképzéses NLES-el néhány mJ-os, tökéletes minőségü, egyciklusú THz-es nyalábokat lehet előállítani, addig a leképzés nélküli forrással (egy kismértékü nyalábminőség romlás mellett) jelentősen megnövelhető a THz-keltésre használt kristályfelület és ezzel együtt a keltett THz-es impulzus energiája. A reflexiós NLS esetén semmilyen korlátozó tényező nincs a pumpáló nyaláb keresztmetszetét tekintve, a THz-es impulzusok energiája a pumpáló lézer energiájával skálázható. A nyalábminőség tökéletes (a térerősség időbeli lefutása mindenhol azonos a nyaláb keresztmetszete mentén), ám egyciklusú impulzusokat csak hosszabb ( 500-700fs) pumpáló impulzusok esetén állíthatunk elő.

\section{Köszönetnyilvánítás}

A munkát az EFOP-3.6.2-16-2017-00005 azonosító számú, Ultra-gyors fizikai folyamatok atomokban, molekulákban, nanoszerkezetekben és biológiai rendszerekben címü projekt, az 125808 számú Terahertzes részecskegyorsítás címủ OTKA-pályázat, és a Bolyai János Kutatási Ösztöndíj (T. Gy.) támogatta.

\section{Irodalom}

[1] J. Hebling, G. Almási, I. Z. Kozma and J. Kuhl, Opt. Express 10, 1161-1166 (2002). https://doi.org/10.1364/OE.10.001161

[2] P. Sanén, M. Basini, S. Bonetti, J. Hebling, M. Krasilnikov, A. Y. Nikitin, G. Shamuilov, Z. Tibai, V. Zhaunerchyk, and V. Goryashko, Phys. Rep. 836-837, 1-74 (2019).

https://doi.org/10.1016/j.physrep.2019.09.002

[3] J. Hebling, J. A. Fülöp, M. I. Mechler, L. Pálfalvi, C. Tőke, and G. Almási, arXiv:1109.6852 (2011).

[4] E. A. Nanni, W. R. Huang, K.-H. Hong, K. Ravi, A. Fallahi, G. Moriena, R. J. D. Miller, and F. Kärtner, Nat. Commun. 6, 8486 (2015).

https://doi.org/10.1038/ncomms9486

[5] Z. Tibai, M. Unferdorben, Sz. Turnár, A. Sharma, J. A. Fülöp, G. Almási, and J. Hebling, J. Phys. B 51, 134004 (2018).

https://doi.org/10.1088/1361-6455/aac1f2

[6] L. Pálfalvi, J. A. Fülöp, Gy. Tóth, and J. Hebling, Phys. Rev. Spec. Top.-AC 17, 031301 (2014). https://doi.org/10.1103/PhysRevSTAB.17.031301

[7] Gy. Tóth, Z. Tibai, A. Sharma, J. A. Fülöp, and J. Hebling, J. Opt. Soc. Am. B 35, A103-A109 (2018).

https://doi.org/10.1364/JOSAB.35.00A103 
[8] C. Hwayeong, Y. Hee-Jin, C. Moran, and S. Joo-Hiuk, Biomed. Opt. Express 10, 4931-4941 (2019). https://doi.org/10.1364/BOE.10.004931

[9] K. Ravi, W. R. Huang, S. Carbajo, X. Wu, and F. Kärtner, Opt. Express 22, 20239-20251 (2014). https://doi.org/10.1364/OE.22.020239

[10] L. Wang, Gy. Tóth, J. Hebling, and F. Kärtner, Laser Photonics Rev. 14, 2000021 (2020). https://doi.org/10.1002/lpor.202000021

[11] J. A. Fülöp, L. Pálfalvi, G. Almási, and J. Hebling, Opt. Express 18, 12311-12327 (2010). https://doi.org/10.1364/OE.18.012311

[12] B. K. Ofori-Okai, P. Sivarajah, W. R. Huang, K. A. Nelson, Opt. Express 24, 5057-5068 (2016). https://doi.org/10.1364/OE.24.005057

[13] Y. Avetisyan, A. Makaryan, V. Tadevosyan, and N. Tonouchi, J. Infrared, Millimeter, Terahertz Waves 38, 1439-1447 (2017). https://doi.org/10.1007/s10762-017-0429-3

[14] L. Pálfalvi, Gy. Tóth, L. Tokodi, Zs. Márton, J. A. Fülöp, G. Almási, and J. Hebling, Opt. Express 25, 29560-29573 (2017).

https://doi.org/10.1364/OE.25.029560

[15] Gy. Tóth, L. Pálfalvi, J. A. Fülöp, G. Krizsán, N. H. Matlis, G. Almási, and J. Hebling, Opt. Express 27 7762-7775 (2019).

https://doi.org/10.1364/OE.27.007762

[16] Gy. Tóth, L. Pálfalvi, Z. Tibai, L. Tokodi, J. A. Fülöp, Zs. Márton, and J. Hebling, Opt. Express 27, 30681-30691 (2019).

https://doi.org/10.1364/OE.27.030681

[17] G. Krizsán, Z. Tibai, J. Hebling, L. Pálfalvi, G. Almási, and Gy. Tóth, Opt. Express 28, 3432034327 (2020).

https://doi.org/10.1364/OE.405748

[18] P. S. Nugraha, G. Krizsán, Cs. Lombosi, L. Pálfalvi, Gy. Tóth, G. Almási, J. A. Fülöp, and J. Hebling, Opt. Lett. 44, 1023-1026 (2019).

https://doi.org/10.1364/OL.44.001023

[19] G. Illés, S. Balázs, M. Anna, Z. Tibai, L. Pálfalvi, G. Almási, J. Hebling, and Gy. Tóth, előkészítés alatt. 